\title{
DíVIDA PÚBLICA, CRÉDITO PúBLICO, ORÇAMENTO E INTERVENÇÃO NO DOMÍNIO ECONÔMICO
}

\subsection{BREVE INTRÓITO}

Neste capítulo, diante da larga utilização da contração da dívida pública, buscar-se-á demonstrar sua relevância como instrumento de intervenção no domínio econômico, pois, como adverte Fernando Pérez Royo, “a dívida pública representa a segunda mais importante dentre as formas de receita à disposição do Estado" ${ }^{\text {”27. }}$.

Nesta obra propõe-se, assim, a abordar os conceitos de crédito público, empréstimo público, endividamento e dívida pública, sua natureza jurídica, características, classificações e, por fim, apontar a relevância e influência que a dívida pública exerce sobre o domínio econômico.

Rogério de Menezes Corigliano ${ }^{428}$ anota que o uso e o emprego do empréstimo público antecedem a era cristã. $\mathrm{O}$ autor indica alguns registros históricos, os quais fariam menção a negócios que assim o caracterizariam e, ao mesmo tempo, também ressalva ser impossível precisar um fato histórico que indique quando os governantes e os Estados passaram a se valer desse instituto.

Nessa mesma linha, Aliomar Baleeiro ${ }^{429}$ relata que apenas alguns textos se limitam a prestar esclarecimentos acerca da finalidade dos empréstimos, dos juros

\footnotetext{
${ }^{427}$ ROYO, Fernando Pérez. Derecho financiero y tributario: parte general, p. 547: "la deuda pública representa la segunda en importancia entre las formas de ingreso a disposición del Estado". ${ }^{428}$ CORIGLIANO, Rogério de Menezes. Empréstimos públicos. 2003. Dissertação (Mestrado) Faculdade de Direito da Universidade de São Paulo, São Paulo, 2003, f. 26.

${ }^{429}$ BALEEIRO, Aliomar. Uma introdução à ciência das finanças, p. 432-433.
} 


\section{•• O orçamento como instrumento de intervenção no domínio econômico}

cobrados à época e as circunstâncias que cercavam a celebração, cobrança e extinção dos contratos. Dentre eles, cita os empréstimos tomados por Atenas para aquisição de barcos de guerra, cujos fatos são relatados por Xenofonte; o empréstimo contraído por Cartago para pagar indenizações decorrentes da batalha de Zama; e, ainda, a correspondência trocada entre Cícero com Ático, a qual tem por objeto os empréstimos concedidos por banqueiros.

A grande diferença que se nota entre o modelo empregado naquela época e o atual é o fato de os empréstimos estarem atrelados à pessoa do governante, do rei ou imperador, pois eram tomados com o propósito de atender a suas necessidades e vontades pessoais e não com o de satisfazer os interesses públicos.

Com isso, prevaleciam a insegurança e a cobrança de juros muito altos, pois, na maioria das vezes, aqueles que sucediam o reino ou o império se negavam a honrar a dívida contraída por seu antecessor alegando, justamente, o fato de essas dívidas terem sido contraídas pessoalmente, e não pelo reino.

$\mathrm{Na}$ Idade Média, e ainda que a contração fosse mais frequente, nenhuma alteração significativa é apontada pela doutrina.

Os empréstimos públicos continuavam a se revestir do caráter de obrigação pessoal do governante e, na maioria das vezes, destinavam-se ao financiamento das guerras, que induziam os credores ou prestamistas a exigir "juros onerosíssimos e garantias humilhantes, que iam desde o fio da barba sacratíssima de Sua Majestade, príncipes tomados como reféns, relíquias de santos, até o penhor da coroa, joias ou a vinculação de certas rendas ao serviço de juros e amortizaçôes da dívida" ${ }^{330}$.

Já na Idade Moderna, para se ter ideia do significado e importância que os empréstimos públicos e a palavra crédito tomaram, basta visitar as obras de William Shakespeare, cujas noções marcaram uma época e ainda hoje fazem parte dos pensamentos econômicos, pois estão intimamente atreladas ao que se entende, ou se compreende, por produção, troca, distribuiçãao e consumo de riqueza ${ }^{431}$.

Escritas durante o Período Elisabetano ou Período Isabelino, compreendido pelos anos de 1558 até 1603, então reconhecido como a "era dourada da história inglesa", o teatro assumiu a posição de difundidor de conhecimento em massa, tendo em vista a inexistência de outros meios de comunicação e a escassez de obras

430 BALEEIRO, Aliomar. Uma introdução à ciência das finanças, p. 434.

431 FRANCO, Gustavo H. B.; FARNAM, Henry W. Shakespeare e a economia. Rio de Janeiro: Zahar, 2009. p. 126. 
escritas, geralmente reservadas àqueles com melhores condições financeiras, poder ou aos quais por estes eram limitadas.

O teatro, na Inglaterra, e diante das peças de Shakespeare, tomou proporções jamais vistas durante o referido período, sendo possível constatar nas obras desse autor fatos que demonstram profundas transformações na economia, então decorrentes da expansão do império e da exploração do mercado exterior.

Como prefere Henry Farnam, o teatro era "uma usina criadora de palavras e sobretudo de combinações entre elas de enorme valor, tal como nos mercados, onde circulavam as moedas, multiplicando as trocas e as riquezas" ${ }^{132}$.

$\mathrm{Na}$ época, Shakespeare retratava os fatos vivenciados por si, pela sociedade e, principalmente, as atitudes tomadas pela rainha, a ponto de mencionar em suas peças a implantação de uma política monetária restritiva e tratar do saneamento do meio circulante como instrumentos de reorganização do sistema monetário, implantados por Elisabeth I. Relata, ainda, a existência de pelo menos trinta e seis diferentes moedas nacionais e estrangeiras que circulavam sem restrição alguma, tanto quanto o convívio com a inflação, as trapaças monetárias, os pacotes econômicos e até mesmo a criação do token fiduciário, o qual era produzido com metais de baixo valor e se destinava à circulação, como moeda de troca ${ }^{433}$.

Reconhecido como a época em que se firmava a noção de "boa moeda", o período histórico em questão foi marcado pelo

(...) extraordinário crescimento das relações crédito/débito interpessoal, acarretando novas formas de subjetividade que o teatro viria a capturar. Formas novas de negociabilidade e compensação de dívidas das quais resultou uma importantíssima inovação financeira, a inland bill of exchange, que permitiu o crescimento da economia "sem uma expansão proporcional na cunhagem de moedas". (Coinage, no original.) ${ }^{434}$

Dentre as inúmeras passagens textuais retratadas por Shakespeare, identifica-se sem dificuldade - por exemplo, em O mercador de Veneza (1596-1598) ${ }^{435}$,

432 FRANCO, Gustavo H. B.; FARNAM, Henry W. Shakespeare e a economia, p. 28.

433 FRANCO, Gustavo H. B.; FARNAM, Henry W. Shakespeare e a economia, p. 29-34.

${ }^{434}$ FRANCO, Gustavo H. B.; FARNAM, Henry W. Shakespeare e a economia, p. 34.

435 Antítese de Tímon de Atenas, Shakespeare, em $O$ mercador de Veneza, toma como tema central o sacrifício em prol da amizade. Antônio, amigo de Bassânio, assume uma obrigação financeira que quase lhe custa a vida, para ajudá-lo a levar adiante uma corte amorosa. Além da amizade, a peça aborda o antagonismo resultante do choque entre as concepções medieval e moderna de juros, fazendo menção à proibição constante do Velho Testamento, de que um judeu cobrasse juros de outro judeu e o fato de que o ouro não produz ouro, além da usura e uma discussão sobre versão extremada do laissez-faire. 
Medida por medida (1603-1604) ${ }^{436}$ e Tímon de Atenas (1605) ${ }^{437}$ - o emprego do termo crédito como instrumento destinado a facilitar o comércio e

(...) suas implicações no domínio das finanças públicas e da expansão do crédito, o qual incorporava conceitos modernos no tocante à propriedade, sua transferibilidade, bem como o reconhecimento e negociabilidade de dívidas e créditos, sobretudo através das letras de câmbio, e quanto a cobrança de juros ${ }^{438}$.

Nota-se, com isso, que o vocábulo crédito, já àquela época, era intimamente atrelado ao termo confiança ou crença $a^{439}$, ainda hoje utilizado.

É possível, também, notar nas peças teatrais mencionadas a evolução do que se deve compreender por crédito, débito, fidúcia, divida e empréstimo, tanto quanto as transformações que esses institutos sofreram ao longo do tempo e as consequências geradas no desenvolvimento de um complexo sistema bancário e de crédito, em que as letras de câmbio e hipoteca eram comumente utilizadas ${ }^{440}$, a ponto de se tornaram determinantes para o aperfeiçoamento do que hoje se compreende por dívida pública.

Percebe-se que, ao longo do tempo, cada vez mais os Estados soberanos se valem dos empréstimos públicos como instrumento financeiro para obtenção de recursos destinados à realização de despesas públicas, e não mais apenas para realização das despesas extraordinárias, como antes se pregava.

As novas funções assumidas pelo Estado, destacadas no primeiro capítulo da presente dissertação, demonstram a necessidade de se encontrar outras fontes de recursos. Tendo como marco inicial o surgimento do que se denomina Estado Fis$\mathrm{cal}^{441}$, no qual, com o fim do feudalismo e com a separação entre o ius eminens e o

436 Nesta trama, a questão central gira em torno de uma questão de controle social, a execução da lei em seu sentido literal, desconsiderando os padrões sociais de seu tempo ou a necessidade de ser conivente com males que não se pode erradicar. O duque, responsável pelo cumprimento da lei, assume um disfarce para ver as coisas de um ponto de vista imparcial e as encontra podres, o que o induz a entregar o governo de seu Estado a um delegado que, "vestido com fortuita autoridade", trata de executar a lei literalmente, até se descobrir violando-a.

437 A obra é marcada pelo retrato de um homem rico e generoso; tão generoso que chega a falir para ser gentil com os amigos que, posteriormente, diante de seu empobrecimento, viram-lhe as costas e se negam a lhe emprestar dinheiro. Sua indignação com a ingratidão daqueles que outrora havia ajudado torna-o amargurado, causando-lhe transtornos mentais.

438 FRANCO, Gustavo H. B.; FARNAM, Henry W. Shakespeare e a economia, p. 51.

439 ORÍA, Salvador. Finanzas. Buenos Aíres: Guillermo Kraft, 1948. v. 3, p. 7.

440 ORÍA, Salvador. Finanzas, p. 249.

441 Para Massonetto, "O Estado Fiscal constitui, desta forma, um mecanismo de estabilização das finanças públicas, assentado na formação de uma fazenda pública, distinta do patrimônio do 
poder tributário, entre a fazenda pública e a fazenda do príncipe, e entre a política e a economia, é que se desenvolve uma mudança de perfil da receita pública, a qual passa, além dos tributos, a contar com os empréstimos autorizados e garantidos pelo Legislativo ${ }^{442}$.

Superados determinados estigmas dos séculos XVII e XVIII, criados por intelectuais e filósofos como Montesquieu, Jean-Baptiste Colbert, Saint-Simon, François Quesnay, David Hume e Adam Smith, os quais repudiavam o uso de empréstimos públicos, asseverando que estes seriam causadores da ruína das nações ${ }^{443}$, somente a partir de 1930, por influência das ideias de John Maynard Keynes, nota-se maior aceitação de seu uso ${ }^{444}$. Esse novo entendimento ganhou força após a Segunda Guerra Mundial.

Opera-se a partir daí, e de acordo com Giovanni Ingrosso ${ }^{445}$, o desvirtuamento de sua concepção originária de que se estaria diante de um instrumento extraordinário de obtenção de recursos financeiros.

Com o agigantamento do Estado, decorrente de sua evolução de "Estado Polícia" para "Estado Providência", os recursos disponíveis tornaram-se insuficientes à consecução dos fins sociais e ao atendimento das necessidades públicas, socorrendo-se os governantes dos empréstimos públicos como alternativa para satisfazê-las e, com isso, cumprir seu papel social, ao ponto de considerá-los um instituto financeiro permanente ${ }^{446}$.

A utilização dos empréstimos públicos deixa de estar vinculada à ocorrência de situaçōes extraordinárias, provenientes de eventos imprevisíveis e urgentes, como, por exemplo, calamidades públicas, guerra e comoção, os quais não poderiam

príncipe, e na racionalização da burocracia fiscal, responsável pela arrecadação da receita pública." (MASSONETTO, Luís Fernando. O direito financeiro no capitalismo contemporâneo: a emergência de um novo padrão normativo, p. 20).

442 TORRES, Ricardo Lobo. Curso de direito financeiro e tributário, p. 8.

443 BALEEIRO, Aliomar. Uma introdução à ciência das finanças, p. 435.

444 TORRES, Ricardo Lobo, op. cit., p. 217.

${ }^{445}$ INGROSSO, Giovanni. Corso di finanza pubblica. Napoli: Dott Eugenio Jovene, 1969. p. 541-542. Nas palavras do autor: "Si è altresi accenato anche, parlando dei concetti generali in tema di dinamica del fenomeno finanziario e di entrate intese come strumenti dell'attivita finanziaria, alla caratteristica che si riscontra nella attuale attivitá finanziaria, risidente nell'utilizzo che quest'ultima fa del prestito pubblico non più soltanto come strumento straordinario d'acquisizione di mezzi finanziari, bensi come forma d'entrata ordinaria.".

${ }^{446}$ INGROSSO, Giovanni. Corso di finanza pubblica, p. 543; FONROUGE, Carlos M. Giuliani. Derecho financiero, p. 208; VILLEGAS, Héctor Belisario. Curso de finanzas, derecho financiero y tributario. 4. ed. Buenos Aires: Depalma, 1990. t. I, p. 64. 


\section{•• O orçamento como instrumento de intervenção no domínio econômico}

ser suportados apenas com as entradas previstas anualmente no orçamento, destinadas à realização de despesas ordinárias ${ }^{447}$, para tornar-se "outro" meio de obtenção de recursos (rotineiro), decorrente de uma decisão político-econômica, de que se valem os governantes, como poderá ser observado adiante.

\subsection{CONCEITO E ELEMENTOS CONSTITUTIVOS DO CRÉDITO: CONFIANÇA, CAPITAL E TEMPO}

Com o intuito de pôr um divisor de águas, afirmou-se, neste estudo, que, antes, os governantes se valiam das terras, da emissão de moedas, da arrecadação de impostos, da extorsão sobre outros povos ou de doaçôes voluntárias para manter seu aparato e atender às necessidades públicas e que, atualmente, recorrem não só à receita proveniente da arrecadação de tributos, mas, também, a outros mecanismos para obter recursos suficientes para satisfazer as despesas públicas, seja para realizar investimentos, seja para arcar com o déficit fiscal, verificado quando as despesas superam o produto da arrecadação ${ }^{448}$.

Em outras palavras, além da arrecadação tributária e dos ingressos patrimoniais, vistos anteriormente, os Estados valem-se de outras rendas, ditas tradicionalmente extraordinárias, para obter recursos capazes de suportar suas obrigaçōes.

Dentre essas rendas mais utilizadas, encontra-se a contração de dívidas, a qual constitui a faculdade de tomar dinheiro por empréstimo da mesma forma que se valem os particulares para financiar a casa própria, a compra de um veículo e até mesmo os estudos, uma viagem etc.

Em suma, quando o Estado recorre ao crédito que goza no mercado, fazendo-se devedor, cria a dívida pública. Daí o nome de batismo dado ao tema por diversos autores que também o tratam sob a denominação de crédito público ou débito público, indiferentemente e de acordo com a perspectiva de cada observador ${ }^{449}$.

Giovanni Ingrosso ${ }^{450}$ diz que "per debito pubblico devesi intendere l'insieme dei debiti contrati dallo Stato e dagli altri enti pubblici", consistindo o empréstimo público, "una vera e propria cessione di capitale monetario, a fronte della qualle lo Stato o l'Ente pubblico assume l'obbligo della resttituzione del capitale stesso, alla scadenza prevista, e della corresponsione degli interessi”.

${ }^{447}$ INGROSSO, Giovanni. Corso di finanza pubblica, p. 542.

${ }^{448}$ MATIAS-PEREIRA, José. Finanças públicas: a política orçamentária no Brasil. 3. ed. São Paulo: Atlas, 2006. p. 143.

449 ATALIBA, Geraldo. Empréstimos públicos e seu regime jurídico. São Paulo: RT, 1973. p. 13.

${ }^{450}$ INGROSSO, Giovanni. Corso di finanza pubblica, p. 557. 
Da definição apresentada, nota-se que a dívida pública é composta pelo capital financeiro, ou recursos, tomados pelo Estado ou seus organismos autônomos perante terceiros ${ }^{451}$, cuja expressão, de acordo com Fernando Sainz de Bujanda ${ }^{452}$, pode ser definida como se segue:

Con la expresión "crédito público" se alude a la possibilidad por parte de un ente público de aprovecharse de la confianza de que puede gozar por parte de otros sujetos de derecho (público o privado) para lograr los medios con que subvenir a sus necessidades.

Demonstra-se, com isso, que a confiança ainda hoje constitui o principal elemento do crédito, tanto que sua concepção é extraída do próprio termo crédito, o qual se mantém o mesmo desde o início da era cristã. Percebe-se, dos escritos de Shakespeare, a íntima relação do crédito com a ideia de confiança ou fé na conduta de uma pessoa, relacionada a "duas formas de crença: a confiança ou fé na moral de uma pessoa disposta a cumprir com seus deveres e obrigaçóes, e a crença de que poderá cumpri-los, por dispor de meios econômicos” $\$ 53$.

Nessa toada, é importante esclarecer que a dívida pública "abrange apenas os empréstimos captados no mercado financeiro interno ou externo, através de contratos assinados com os bancos e instituições financeiras ou do oferecimento de títulos públicos em geral"454.

Excluem-se, portanto, a emissão de papel moeda e as operações que se caracterizam como dívida da Administração, como, por exemplo, aluguéis, aquisição de bens, prestação de serviços e condenaçõoes judiciais.

Conforme ensinamento de Horacio Guillermo Corti ${ }^{455}$, a operação de crédito público, como mecanismo de obtenção de recursos, dá lugar, de modo imediato, ao nascimento de uma dívida e origem a um gasto público. Ao contrair a dívida pública, compromete-se a renda futura para atender às atuais necessidades financeiras do Estado. Veja-se:

(...) las operaciones de crédito público son todas las técnicas jurídicas mediante las cuales el Estado obtiene recursos financieros obligándose, de forma correlativa, a devolver en cierto plazo la suma obtenida, más un interés. La propia operación de crédito público hace nacer una deuda, de forma que los aspectos recaudatorios y erogatorios no son posibles de escindirr ${ }^{456}$.

451 ROYO, Fernando Pérez. Derecho financiero y tributario: parte general, p. 548.

452 BUJANDA, Fernando Sainz de. Lecciones de derecho financiero. 7. ed. Madrid: Universidad Complutense; Facultad de Derecho, Sección de Publicaciones, 1989. p. 400.

453 ORÍA, Salvador. Finanzas, p. 7.

454 TORRES, Ricardo Lobo. Curso de direito financeiro e tributário, p. 219.

455 CORTI, Horacio Guillermo. Derecho constitucional presupuestario, p. 619.

${ }^{456}$ CORTI, Horacio Guillermo. Derecho constitucional presupuestario, p. 619. 
Geraldo Ataliba ${ }^{457}$ sustenta que, ainda que o Estado possa ser devedor por diversas formas, para se configurar empréstimo público

(...) é preciso que o nascimento da obrigação que o tem no polo negativo - como sujeito passivo, devedor - tenha sido determinada pela livre manifestação de vontade do credor. Só assim se preenche o requisito da contratualidade da relação, conferindo-lhe a qualidade de empréstimo.

Logo, o crédito, ou sua concessão, como já salientado, mostra-se intimamente ligado à ideia de confiança, à fidúcia, ou à fé de que determinada pessoa cumprirá seus deveres e obrigaçōes, tanto quanto terá disponibilidade econômico-financeira para arcar com o pagamento da dívida contraída ao longo do tempo. A propósito, Sérgio Assoni Filho ${ }^{458}$ assinala:

(...) o crédito implica a troca de um bem ou valor no presente por uma promessa de riqueza futura que, aliás, será a responsável pelo reembolso do que foi emprestado e pelo pagamento dos juros ou outros benefícios oferecidos aos prestamistas.

Em outras palavras, como relata Geraldo Ataliba ${ }^{459}$, "o empréstimo em dinheiro, como instituto jurídico, leva em consideração, objetiva e subjetivamente, a confiança que pode merecer uma determinada pessoa, para o cumprimento de uma determinada obrigação".

É possível afirmar, portanto, que os elementos constitutivos do crédito são a confiança, a existência de capital e o fator tempo, pois, como já salientado por Geraldo Ataliba ${ }^{460}$, "as relaçôes jurídicas de direito público e privado, que se reúnam sob a designação genérica de empréstimo, são revestidas das mesmas qualidades essenciais".

E, diante dos elementos constitutivos do crédito, os quais "aplicam-se ao crédito de forma genérica, abrangendo tanto a ideia de crédito público quanto a de crédito privado", há que se reconhecer a dificuldade em distingui-los, pois entre eles "é bastante sensível e centrada essencialmente na natureza do tomador do empréstimo, bem como na finalidade por ele encampada no momento em que recorre à operação de crédito"’461.

Há, assim, que se reconhecer que o crédito público e, por conseguinte, todas as operaçôes, tais como aquelas verificadas nas transações privadas, devem pautar-se

${ }^{457}$ ATALIBA, Geraldo. Empréstimos públicos e seu regime jurídico, p. 26.

458 ASSONI FILHO, Sérgio. Crédito público e responsabilidade fiscal. Porto Alegre: Nuria Fabris, 2007. p. 18.

459 ATALIBA, Geraldo, op. cit., p. 15.

${ }^{460}$ ATALIBA, Geraldo. Empréstimos públicos e seu regime jurídico, p. 10.

${ }^{461}$ ATALIBA, Geraldo. Empréstimos públicos e seu regime jurídico, p. 19. 
por valores de lealdade, coerência e colaboração, fundando-se o contrato na credibilidade e confiança.

\subsection{OS EMPRÉSTIMOS PÚBLICOS E AS RECEITAS ORDINÁRIAS}

No Capítulo 3, o presente estudo valeu-se da definição de Regis Fernandes de Oliveira, para afirmar que receita pública "é a entrada definitiva de dinheiro e bens nos cofres públicos" ${ }^{\prime 62}$.

Além disso, no tocante às receitas públicas, relatou-se que estas se classificam de acordo com (i) a periodicidade e (ii) a origem.

No caso da periodicidade, as receitas se subdividem em extraordinárias, quando ocorre o ingresso excepcional de recursos, destinados a atender a situaçóes imprevistas e indesejáveis (art. 154, II, da CF/1988); e ordinárias, quando havidas com regularidade, decorrente do desenvolvimento regular da atividade estatal (por exemplo, com a cobrança de impostos).

No que toca à origem, elas se subdividem em originárias, derivadas e transferidas, isto é, de modo sintético, trata-se, respectivamente, daquelas decorrentes da exploração pelo Estado de seus próprios bens, do constrangimento sobre o patrimônio do particular ou, então, daquelas que, embora provenientes do patrimônio do particular, não são arrecadadas pela entidade política que vai utilizá-las ${ }^{463}$.

$\mathrm{Na}$ situação específica dos empréstimos públicos, o presente estudo também afirma que, embora seja tido como entrada de recursos, pois todo e qualquer dinheiro que ingressa nos cofres públicos assim deve ser considerado, estes não constituem receita. A posição ora externada se coaduna com o entendimento de Regis Fernandes de Oliveira ${ }^{464}$, segundo o qual, todo recurso financeiro que ingressa nos cofres públicos, ainda que provisoriamente, constitui receita, mesmo que depois seja devolvido ao credor ou prestamista.

Remanesceria, apenas, e não fosse o reconhecimento pacífico pelos doutrinadores, dentre os quais cita-se Giovanni Ingrosso ${ }^{465}$, dúvidas atinentes a sua periodicidade, ou seja, se ainda seria possível afirmar que os empréstimos públicos constituem receita extraordinária.

A resposta e algumas considerações acerca dessa indagação se mostram relevantes em face dos propósitos do presente estudo.

\footnotetext{
462 OLIVEIRA, Regis Fernandes de. Curso de direito financeiro, p. 128.

${ }^{463}$ OLIVEIRA, Regis Fernandes de. Curso de direito financeiro, p. 129-130.

${ }^{464}$ OLIVEIRA, Regis Fernandes de. Curso de direito financeiro, 126-127.

${ }^{465}$ INGROSSO, Giovanni. Corso di finanza pubblica, p. 546-547.
} 
Ao reconhecer os empréstimos públicos como receitas extraordinárias, estaria afastada a possibilidade de serem os recursos obtidos utilizados para a realização de despesas ordinárias? Ainda, por serem destinados à realização de despesas extraordinárias, estaria o contraente impossibilitado de efetuar gastos em infraestrutura ou conceder estímulos à economia com os recursos financeiros obtidos?

Diante das indagaçôes colocadas, mostram-se pertinentes as considerações de Fernando Sainz de Bujanda ${ }^{466}$, quando sustenta que o caráter extraordinário da dívida não perdeu totalmente seus valores, podendo encontrar dentre os motivos que podem induzir o Estado a contrair dívida, a necessidade de fazer frente a gastos extraordinários e a impossibilidade de aumentar a carga tributária. Tudo sem prejuízo de se aceitar a relatividade da categoria de gastos extraordinários.

Ricardo Lobo Torres ${ }^{467}$, ao tratar do tema, embora não considere o empréstimo público um tipo de receita pública, é claro ao afirmar que os empréstimos perderam o caráter de medida extraordinária e passaram a ingressar no orçamento fiscal, juntamente com a previsão para o pagamento dos juros e das amortizações.

Nesse aspecto, vale trazer a definição de dívida pública divulgada pela Secretaria do Tesouro Nacional do País: "dívida pública - dívida contraída pelo governo com o objetivo de financiar gastos não cobertos com a arrecadação de impostos" ${ }^{\prime \prime 68}$.

$\mathrm{Na}$ atualidade, a dívida pública constitui um meio normal de o Estado obter recursos e, como já assinalado, um instituto permanente, afastando as circunstâncias extraordinárias que antigamente justificavam sua contração, o que induziu vários autores a afirmarem que os recursos financeiros provenientes de empréstimos públicos passaram a deter a natureza de ingressos ordinários.

${ }^{466}$ BUJANDA, Fernando Sainz de. Lecciones de derecho financiero, p. 404. Nas palavras do autor: "Sin embargo, el carácter extraordinario que tradicionalmente se ha atribuido a la Deuda, basándose en las razones anteriormente apuntadas, no ha perdido todo su valor en la actualidad. Con él se alude muchas veces a que, entre los motivos que puedan inducir al Estado a contraer deuda, puede encontrarse la necesidad de hacer frente a gastos extraordinarios y la impossibilidad de forzar más los ingresos tributarios. Sin perjuicio de aceptar la relatividad de esta categoría de gastos extraordinarios, es desde este punto de vista desde el que se puede criticar una política de ingresos fáciles que recurra al crédito para hacer frente a los gastos ordinarios del Estado".

467 TORRES, Ricardo Lobo. Curso de direito financeiro e tributário, p. 218.

${ }^{468}$ Disponível em: <http://www.tesouro.fazenda.gov.br/glossario-do-tesouro-direto>. Acesso em: 17 out. 2014. 
Como pondera Héctor Villegas Belisario"469, "la teoría moderna se orienta hacia la idea de que el empréstito es un recurso que nada tiene de anormal, y que no puede estar rígidamente limitado a circunstancias excepcionáis”.

Essa orientação se deve não apenas à necessidade do Estado, de se socorrer de outros meios de obtenção de recursos para atender a seus propósitos, os quais se alargaram sobremaneira, mas, também, em face da habitualidade com que passaram a contrair dívidas, deixando o empréstimo de ser mero ingresso excepcional e esporádico.

\subsection{NATUREZA JURÍDICA}

Estabelecido que a receita proveniente da contração de dívida é considerada um instituto permanente do fenômeno financeiro e apresentadas suas principais definições e elementos constitutivos de forma genérica, faz-se necessário distinguir o crédito público do privado, o que somente se mostra possível mediante a análise e compreensão da natureza jurídica do empréstimo público.

Por cautela, adverte-se que a modalidade de empréstimo público a ser analisada, e que dá origem à dívida pública, é originária do mútuo, tal qual estabelece o Código Civil, nos arts. $586^{470}$ e $591^{471}$, dentre outros.

São esclarecedoras as palavras de José Maurício Conti ${ }^{472}$, ao distinguir o $m u ́-$ tuo da figura jurídica do financiamento:

Empréstimo é o gênero do qual são espécies o mútuo e comodato. A menção a empréstimos ora feita é referente à espécie mútuo. Mútuo é um tipo de contrato que cria a obrigação ao mutuário de restituir ao mutuante o que dele recebeu, tendo como características principais o fato de ter como objeto coisas fungíveis, ser temporário e real, e permite a estipulação de juros (Código Civil, arts. 1.256 e ss.). Financiamento é um tipo de negócio jurídico que normalmente se dá entre instituição financeira, que adianta recursos, a alguém que deles necessite para algum empreendimento. Em geral vincula-se a outro negócio jurídico, como a importação de bens.

469 VILLEGAS, Héctor Belisario. Curso de finanzas, derecho financiero y tributario, 9. ed., p. 64.

470 Conforme redação do Art. 586, "O mútuo é o empréstimo de coisas fungíveis. O mutuário é obrigado a restituir ao mutuante o que dele recebeu em coisa do mesmo gênero, qualidade e quantidade."

$471 \mathrm{O}$ art. 591 reza o seguinte, "Destinando-se o mútuo a fins econômicos, presumem-se devidos juros, os quais, sob pena de redução, não poderão exceder a taxa a que se refere o art. 406, permitida a capitalização anual.".

472 CONTI, José Maurício. Direito financeiro na Constituição de 1988. São Paulo: Oliveira Mendes, 1998. p. 70-71. 


\section{•• O orçamento como instrumento de intervenção no domínio econômico}

Vale lembrar que, para alguns autores, o empréstimo público submete-se aos mesmos princípios que norteiam o empréstimo privado, dentre os quais se apresenta a livre manifestação de vontade em contraposição à compulsoriedade, cuja característica é inerente aos tributos. Os tributos, por sua vez, constituem outra fonte de receita pública ao lado dos empréstimos públicos, distinguindo-se no que toca à obrigatoriedade de devolver o valor arrecadado.

De todo modo, e como destaca com precisão Fernando Sainz de Bujanda ${ }^{473}$, a utilização do crédito não é o único meio de endividamento do Estado, o que pode se dar mediante uma série de outros mecanismos, devendo, por isso, cada um deles ser analisado de acordo com cada caso e dentro dos limites de cada figura jurídica.

É o que se constata da leitura do inc. III, do art. 29, da LRF, em que operação de crédito é definida como sendo o compromisso financeiro assumido em razão de mútuo, abertura de crédito, emissão e aceite de título, aquisição financiada de bens, emissão e aceite de título, aquisição financiada de bens, recebimento antecipado de valores provenientes da venda a termo de bens e serviços, arrendamento mercantil e outras operações assemelhadas, inclusive com o uso de derivativos financeiros.

Nesse aspecto, como ressalta Regis Fernandes de Oliveira ${ }^{474}$, torna-se necessário esclarecer que antes mesmo do advento da Lei de Responsabilidade Fiscal, para a doutrina, as operações de crédito não se referiam apenas aos contratos de empréstimo.

É, no entanto, diante de todas essas observaçôes e pormenores que surgem posições antagônicas acerca da natureza jurídica dos empréstimos públicos, as quais estão longe de alcançar qualquer consenso.

Para Giuliani Fonrouge, por exemplo, "el empréstito público tiene el carácter de una obligación unilateral de derecho público, derivada de la soberanía, y en su forma clásica de operaciones a largo plazo y a plazo intermedio ha originado la idea errónea de que se trata de un contrato" ${ }^{\text {"475. }}$.

Fernando Sainz de Bujanda ${ }^{476}$, por sua vez, sustenta que os empréstimos públicos detêm natureza jurídica contratual regida pelo direito público e que, portanto, estar-se-ia diante de um contrato administrativo; afinal, "cuando la Administración contrata Deuda pública defiende un interés colectivo primario, posibilitando el desarrollo de los servicios públicos de actividad total del Estado’’477.

\footnotetext{
473 BUJANDA, Fernando Sainz de. Lecciones de derecho financeiro, p. 401.

474 OLIVEIRA, Regis Fernandes de. Responsabilidade fiscal. 2. ed. São Paulo: RT, 2002. p. 73.

${ }^{475}$ FONROUGE, Carlos M. Giuliani. Derecho financiero, p. 208.

476 BUJANDA, Fernando Sainz de, op. cit., p. 404-407.

477 BUJANDA, Fernando Sainz de, op. cit., p. 407.
} 
Essa concepção dá origem a uma terceira teoria, a qual também confere aos empréstimos públicos caráter tipicamente contratual, porém, defende a posição de que esses seriam regidos pelo direito privado.

Assim, diante das diversas teorias envolvendo a natureza jurídica do empréstimo público, a presente dissertação limitar-se-á à análise das três apontadas há pouco por considerá-las as mais relevantes. Para essa análise, divide-as, como a própria doutrina sugere, entre aqueles que afirmam tratar-se de uma (i) obrigação unilateral autônoma de direito público e aqueles que dizem tratar-se de (ii) contrato, os quais, por sua vez, se subdividem entre os defensores segundo os quais este é regido pelo (ii.a) direito privado e os defensores da ideia de este ser regido pelo (ii.b) direito público.

Saliente-se que, em razão de essas teorias já terem sido examinadas à exaustão por Regis Fernandes de Oliveira ${ }^{478}$ e Sérgio Assoni Filho ${ }^{479}$, tomar-se-á, nesta dissertação, a liberdade de expor apenas os pontos e as questóes mais relevantes.

Dentre os adeptos da primeira corrente destacam-se Carlos M. Giuliani Fonrouge, Saygués Laso, Luis María Drago, Giovanni Ingrosso, Sá Filho, os quais propugnam a concepção de que os empréstimos públicos constituem uma obrigação unilateral autônoma de direito público em que as condiçôes fixadas se traduziriam em um ato de soberania do Estado. Esse ato, por sua vez, daria origem a uma obrigação unilateral de direito público.

Os adeptos dessa teoria também propugnam que, por se tratar de um ato de soberania, seria inadmitida a execução forçada da dívida pelo credor, a qual ganhou relevo quando uma esquadra mista, formada pela Inglaterra, Alemanha e Itália, bombardeou São Carlos, em decorrência da bancarrota da Venezuela.

Esse fato deu origem à chamada "doutrina de Drago", a qual fora exposta em nota datada de 29 de dezembro de 1902, subscrita pelo então Ministro do Exterior da Argentina, Luis María Drago, e entregue ao Departamento de Estado em Washington ${ }^{480}$.

Em referida nota, Luis María Drago repudia a cobrança militar dos empréstimos e assinala que de maneira alguma defende a má-fé, a desordem e a insolvência deliberada e voluntária, devendo ser assegurada a liberdade das nações ${ }^{481}$, isto é, sua soberania.

478 OLIVEIRA, Regis Fernandes de. Curso de direito financeiro, p. 660-665.

479 ASSONI FILHO, Sérgio. Crédito público e responsabilidade fiscal, p. 29-48.

480 BALEEIRO, Aliomar. Uma introdução à ciência das finanças, p. 473.

${ }^{481}$ Nas palavras do autor: "No es ésto de ninguna manera defender la mala fe, el desorden y la insolvencia deliberada y voluntaria. Es simplemente amparar el decoro de la entidad pública 
Para Regis Fernandes de Oliveira ${ }^{482}$, a teoria em foco - da obrigação unilateral autônoma de direito público - não se sustenta porque são necessários dois atos jurídicos autônomos para que a contração do empréstimo público se opere efetivamente - (i) o ato de autorização legislativa e (ii) o ato de concretização do empréstimo. O primeiro ato somente produz efeitos com a promulgação da lei pertinente, momento em que se opera a alteração da ordem normativa, o que, portanto, constitui ato de soberania do Estado. O segundo ato, por sua vez, consistente na efetiva contratação e, portanto, decorre da livre manifestação daqueles que pretendem contratar com o Estado, seja adquirindo seus títulos, seja emprestando-lhe algum dinheiro.

Assim, por se tratar de ato bilateral, produto da livre manifestação de vontade do contratante, não mais se estaria diante de um ato de soberania que, no entendimento do presente estudo e já adiantando, não retira o caráter contratual dos empréstimos públicos, nem tampouco impede a propositura da competente demanda judicial, tendente a compelir o Poder Público a cumprir o contratado.

A propósito, Regis Fernandes de Oliveira ${ }^{483}$ assenta:

(...) o que não se admite é a agressão internacional para exigência do débito. O constrangimento militar é inviável, no concerto atual dos países, disciplinada a ordem internacional por obediência a pactos e tratados, embasados e firmados nas noções da não intervenção e da soberania dos Estados.

Exemplo dessa situação é o que se verificou recentemente com a Argentina, ao recusar satisfazer o crédito de um pequeno grupo de investidores, rotulados de "fundos abutres" e cujo investimento correspondia a US \$ 1,5 bilhão da dívida do país.

Diante do inadimplemento, o grupo de credores propôs, perante a Justiça de Nova York, nos Estados Unidos da América, a competente ação judicial, na qual restou decidido pelo pagamento integral em favor dos demandantes e, mais ainda, foi mantida a ordem judicial que proíbe a Argentina de pagar qualquer outro credor enquanto não liquidar o crédito exequendo.

Além disso, a decisão proferida pelo Judiciário norte-americano poderá dar início a uma série de cobranças de pagamentos adicionais, calculados entre US\$15

internacional que no puede ser arrastrada así à la guerra, con perjuicio de los altos fines que determinan la existencia y libertad de las naciones" (DRAGO, Luis María. Cobro coercitivo de deudas públicas. Buenos Aires: Coni Hermanos, 1906. p. 14).

${ }^{482}$ OLIVEIRA, Regis Fernandes de. Curso de direito financeiro, p. 661-662.

${ }^{483}$ OLIVEIRA, Regis Fernandes de. Curso de direito financeiro, p. 662. 
e 20 bilhões, o que certamente contribuirá para agravar a crise econômica e financeira enfrentada no país, cujos reflexos são sentidos em toda a América Latina ${ }^{484}$.

Como demonstrado pelo exemplo citado, a posição defendida por aqueles que comungam da ideia de se tratar de uma obrigação unilateral autônoma de direito público já não se sustenta por completo.

Para Regis Fernandes de Oliveira ${ }^{485}$, a soberania do Estado impede que este sofra agressão internacional e, ainda que se verifique a impenhorabilidade dos bens públicos, esta não impede o ajuizamento da competente ação judicial, nem tampouco posterior satisfação do débito exequendo, o qual, no Brasil, dar-se-ia de acordo com o rito previsto no art. 100 da CF/1988, com a inclusão do precatório no orçamento.

Nesse sentido já se pronunciou Amílcar de Araújo Falcão ${ }^{486}$ e bem esclareceu que:

“(...) um dos pontos de partida da tese anti-contratualista tem em vista o empréstimo externo. Algumas vezes, Estados credores tentaram constranger militarmente Estados devedores inadimplentes a solverem os seus débitos decorrentes de empréstimos externos.

A condenação de tal procedimento, que encontrou na doutrina de Drago o seu ponto culminante, tinha como um dos seus fundamentos a assertiva de ser o empréstimo público um ato de soberania e, portanto, não comportar a sua prática ou as decorrências que dela provenham execução forçada ou coativa, tanto no plano interno, como no âmbito externo".

Não se admite, portanto, a agressão armada em que se verificaria "um atentado contra a soberania do Estado a que se dirige, qualquer que seja a natureza do ato, contratual, legislativo, jurisdicional, ato político, ou outro, que tenha sido tomado como motivo da agressão" ${ }^{\text {"487. }}$.

Os defensores da segunda corrente, por sua vez, dão ao contrato característica tipicamente contratual, remanescendo, como já advertido, a discussão acerca de seu regime jurídico, se é regido pelo direito privado ou pelo direito público.

${ }^{484}$ Disponível em: <http://g1.globo.com/jornal-da-globo/noticia/2014/07/argentina-da-calote-na-divida-externa-pela-segunda-vez-em-treze-anos.html>. Acesso em: 27 out. 2014.

485 OLIVEIRA, Regis Fernandes de. Curso de direito financeiro, p. 662.

${ }^{486}$ FALCÃO, Amílcar de Araújo. Natureza dos empréstimos públicos. Revista de Direito Público, ano IV, v 13, jul.-set. 1973, p. 12.

${ }^{487}$ FALCÃO, Amílcar de Araújo. Natureza dos empréstimos públicos. Revista de Direito Público, ano IV, v 13, p. 13. 
Estudiosos como Gabriel Franco, Henri Laufenburger, Alberto Deodato e Paul Laband estão entre os que afirmam tratar-se de contrato regido pelo direito privado e, em razão disso, defendem a teoria de que os empréstimos públicos devem seguir a disciplina jurídica do mútuo traçado no sistema jurídico nacional, ou seja, pelo Código Civil, e, portanto, seriam regidos pelo direito privado.

Gaston Jèze, Guido Zanobini, Marcel Waline, Louis Trotabas, André de Laubadère, Fernando Sainz de Bujanda, Themístocles Brandão Cavalcanti, José Cretella Júnior e Geraldo Ataliba, dentre outros, apregoam a teoria de que os empréstimos públicos são contratos de direito administrativo, de natureza semelhante à das demais relações contratuais estabelecidas pelo Estado e, assim, regidos pelo direito público.

Nesse passo, mostra-se pertinente trazer à colação os ensinamentos de Fernando Sainz de Bujanda ${ }^{488}$, conforme a seguir:

Pues bien, creemos que se puede afirmar que la actividad que desarrolla la Administración cuando contrata un empréstito la realiza como tal Administración, dotada de poder de imperio y sin colocarse en un plano de igualdad con el particular y que, por tanto, el contrato a que da lugar es un contrato administrativo.

En efecto, cuando la Administración contrata Deuda pública defiende un interés colectivo primario, posibilitando el desarrollo de los servicios públicos de la actividad total del Estado.

En segundo lugar, la presencia de las llamadas "cláusulas exorbitantes", los privilegios que se conceden a los prestamistas, la prescripción especial, la jurisdicción que entiende de los litigios que en torno a estos contratos se promueven, la intención de las partes, etc., ponen de relieve que es un ente público como tal quien contrata, y que la relación a la que se da vida encuentra su régimen jurídico normal en las normas de Derecho Administrativo.

Adepto dessa teoria, segundo a qual os empréstimos públicos constituem contratos de direito público, Regis Fernandes de Oliveira ${ }^{489}$ assim defende: "ele[s] difere [m] do comum não só pela finalidade - ou seja, sempre está presente um interesse público -, mas também pela exigência de forma especial, no caso a lei, e também pela unilateralidade da rescisão e da alteração das denominadas cláusulas regulamentares". O estudioso ${ }^{490}$ ainda esclarece:

Trata-se de contrato de direito público porque: a) deve haver previsão orçamentária; b) exige disposição legal específica do órgão legislativo solicitante; c) há obrigato-

${ }^{488}$ BUJANDA, Fernando Sainz de. Lecciones de derecho financeiro, p. 407.

489 OLIVEIRA, Regis Fernandes de. Curso de direito financeiro, p. 664.

490 Ibidem, p. 664. 
riedade de autorização e controle do Senado; d) necessária a finalidade pública; e) é possível alteração unilateral de determinadas cláusulas, se assim foi previsto na lei;

f) há sujeição a prestação de contas; g) há inviabilidade de execução específica; e

h) pode ocorrer possibilidade de rescisão unilateral (resgate antecipado).

Nessa mesma linha, cujo pensamento também se coaduna com o endossado pela presente dissertação, Sérgio Assoni Filho ${ }^{491}$ afirma:

(...) o empréstimo público é um contrato de direito público (contrato administrativo em sentido estrito), pois é um contrato ofertado pelo ente público tomador, com base em seu crédito, tendo em vista uma finalidade pública, unilateralmente fixando as condições de restituição futura do capital, e que é aceito pelo prestamista, pessoa física ou jurídica, pública ou privada, que dispõe do capital solicitado pelo primeiro.

Consideradas essas posições, vale acrescentar a anotação feita por Geraldo Ataliba $^{492}$, na qual sustenta que o empréstimo público pressupõe a liberdade de contratar, sendo irrelevante que o credor, emprestador, mutuante ou prestamista seja pessoa pública ou privada ou, até mesmo, pessoa de direito internacional.

Reconhecida a natureza contratual do empréstimo público e que este é regido pelo direito público, mostra-se pertinente apresentar o conceito de contrato administrativo proposto por Bandeira de Mello. Para o autor ${ }^{493}$, trata-se de

(...) um tipo de avença travada entre a Administração e terceiros na qual, por força da lei, de cláusulas pactuadas ou do tipo de objeto, a permanência do vínculo e as condições preestabelecidas assujeitam-se a cambiáveis imposições de interesse público, ressalvados os interesses patrimoniais do contratante privado.

Deve-se ressaltar que, ainda que o Estado ou a Administração estabeleça unilateralmente as condições da contratação, isso não lhe retira o caráter contratual, pois o prestamista detém a faculdade de se submeter, ou não, às condiçôes propostas. Existe, portanto, não uma imposição decorrente do poder de império do Estado, mas sim um acordo de vontades ${ }^{494}$.

Deveras, e como já manifestado, este estudo considera que o regime jurídico dos contratos de empréstimo público é o de direito público, o que se deve pela presença do Estado no polo passivo da relação obrigacional e, consequentemente, o envolvimento do interesse público, o qual deve prevalecer sobre o interesse do particular, bem como pela existência de cláusulas especiais que acabam por privilegiar o ente público.

\footnotetext{
491 ASSONI FILHO, Sérgio. Crédito público e responsabilidade fiscal, p. 48.

${ }^{492}$ ATALIBA, Geraldo. Empréstimos públicos e seu regime jurídico, p. 6.

493 MELLO, Celso Antônio Bandeira de. Curso de direito administrativo, p. 626-627.

${ }^{494}$ ASSONI FILHO, Sérgio. Crédito público e responsabilidade fiscal, p. 44.
} 
Em síntese, "genericamente, empréstimo público é o contrato administrativo pelo qual o Estado recebe determinado valor que se obriga a pagar, na forma por ele estipulada" ${ }^{\prime 49}$.

Além de se tratar de contrato administrativo e, com isso, regido pelo direito administrativo, é pertinente ressaltar que deve sempre estar presente o interesse público, ou seja, o interesse do todo, de um conjunto.

\subsection{CLASSIFICAÇÕES}

Reconhecido o atual caráter ordinário da receita gerada com o ingresso de recursos financeiros oriundos de empréstimos contraídos pelo ente público, o presente estudo passa a se ocupar do esforço doutrinário dedicado a propor uma classificação da dívida pública, ainda que, no direito, as classificações existentes não sejam certas nem erradas, mas úteis e inúteis para os propósitos a que se destinam ${ }^{496}$.

O importante, como adverte Regis Fernandes de Oliveira, é que se tenha "em mira o critério de discriminação" para apartar "o material objeto de estudo"

Considerado o propósito traçado logo no início da presente dissertação, o qual se resume em demonstrar que o orçamento público constitui um importante instrumento de intervenção no domínio econômico, a dívida pública assume papel fundamental e relevante.

O ente público, ao optar por contraí-la, ao mesmo tempo abdica do seu poder de império de instituir tributos e arrecadá-los, deixando de onerar a sociedade e a iniciativa privada, bem como onera as geraçōes futuras, mas, também, fomenta determinadas atividades com alocação de recursos, investimentos em obras de infraestrutura, concessão de empréstimos ou incentivos fiscais etc.

Neste cenário, e dentre as várias alternativas presentes no mercado econômico dos prestamistas, adotar-se-á, a classificação sugerida pelo texto constitucional brasileiro, dividindo-as (i) em relação à pessoa jurídica que contraia a dívida (federal, estadual ou municipal); (ii) em relação ao local de pagamento do crédito (internas e externas); e, por fim, (iii) quanto ao seu prazo de duração (dívida consolidada ou fundada e flutuante).

Além das alternativas apontadas pelo texto constitucional, e diante de sua relevância, também será objeto de análise a dívida mobiliária, tendo em vista o tratamento específico recebido pela Lei de Responsabilidade Fiscal.

495 OLIVEIRA, Regis Fernandes de. Curso de direito financeiro, p. 660.

${ }^{496}$ CARRIÓ, Genaro A. Notas sobre derecho y lenguaje, p. 99.

497 OLIVEIRA, Regis Fernandes de. Curso de direito financeiro, p. 672. 


\subsubsection{Dívida federal, estadual e municipal}

Um dos critérios de classificação de classificação da dívida pública propostos consiste em separá-la - a dívida pública - em federal, estadual ou municipal, ou seja, de acordo com o ente da federação que a contrai, o polo subjetivo do contrato ${ }^{498}$. Assim, classifica-se a dívida pública de acordo com a pessoa jurídica de direito público tomadora do empréstimo aos prestamistas ${ }^{499}$, dívida essa que será denominada de acordo com o ente que a contraia - se a União, dívida federal, se um Estado, dívida estadual; se um Município, dívida municipal.

É o que sugere o art. 52, incs. VI e VII, da CF/1988, ao relacionar dentre as competências privativas do Senado Federal, a prerrogativa de fixar, por proposta do Presidente da República, limites globais para o montante da dívida consolidada da União, dos Estados, do Distrito Federal e dos Municípios, bem como dispor sobre os limites globais e condições para as operaçōes de crédito externo e interno dos respectivos entes federativos, suas autarquias e demais entidades controladas pelo Poder Público federal.

No que tange à importância dessa classificação, é pertinente transcrever a observação feita por Sérgio Assoni Filho ${ }^{500}$ sobre o assunto:

Ressalte-se que essa classificação traz à baila a importante questão da competência legislativa, uma vez que, embora os empréstimos públicos a serem contratados por todos os entes federativos devam ter seus limites e condiçôes fixados pelo Senado Federal, apenas os seus respectivos Poderes Legislativos, dentro de suas respectivas esferas, poderão autorizar mediante lei a contratação dos empréstimos.

Cabe, assim, ao Poder Legislativo competente, ou seja, ao Poder Legislativo da respectiva esfera governamental tomadora do empréstimo, autorizar ou não a contratação da dívida, ainda que o Senado Federal detenha competência privativa para dispor sobre os limites globais do crédito interno e externo dos entes federativos (art. 52, VII, da CF/1988).

\subsubsection{Dívida pública externa e interna}

A dívida pública interna e a externa têm causas e consequências distintas, embora possam ter implicações uma sobre a outra.

De forma indireta, o texto constitucional brasileiro, no art. 52, inc. V, também faz referência à presente classificação, ao estabelecer que compete ao Senado

\footnotetext{
498 OLIVEIRA, Regis Fernandes de. Curso de direito financeiro, p. 672.

499 ASSONI FILHO, Sérgio. Crédito público e responsabilidade fiscal, p. 54.

${ }^{500}$ ASSONI FILHO, Sérgio. Crédito público e responsabilidade fiscal, p. 54.
} 


\section{•• O orçamento como instrumento de intervenção no domínio econômico}

Federal, privativamente, autorizar operações externas de natureza financeira, e, no inc. VII do mesmo dispositivo, atribuir-lhe a competência para estabelecer os limites globais e as condições para as operações de crédito externo e interno dos entes da Federação.

O mesmo entendimento se extrai do disposto no art. 163, inc. II, da CF/1988, o qual estabelece que cabe à lei complementar dispor sobre dívida pública externa e interna, incluída a dívida das autarquias, fundações e demais entidades controladas pelo Poder Público.

Essa classificação, como pondera Sérgio Assoni Filho ${ }^{501}$, não contém na doutrina um conceito preciso do que se deve entender por dívida pública interna e externa, havendo uma infinidade de critérios adotados pelos financistas, dentre os quais, citem-se (i) o mercado ou celebração do contrato; (ii) o local de pagamento ou de execução do contrato; (iii) a nacionalidade da moeda adotada; (iv) a nacionalidade dos contratantes; e (v) o ordenamento jurídico aplicável ao contrato.

Nota-se que Regis Fernandes de Oliveira ${ }^{502}$, ao traçar uma distinção, o faz com relação ao local de pagamento do crédito, esclarecendo que:

A interna é emitida e resgatada dentro do mercado de um país, independentemente de serem os mutuários brasileiros ou estrangeiros. A externa não tem caracterização pela moeda de pagamento, mas pela transferência de divisas ao exterior, e, pois, o que importa é o local ou a praça em que o pagamento deva ser feito.

Geraldo Ataliba ${ }^{503}$ e Ricardo Lobo Torres ${ }^{504}$, por sua vez, preferem distingui-las de acordo com a nacionalidade dos contratantes, assinalando, este último, que a "dívida pública interna é a contraída diretamente com as instituições financeiras no País ou através da colocação de títulos do Governo no mercado anônimo de capitais" ${ }^{05}$, enquanto a dívida externa é a

(...) contraída com Estados Estrangeiros, com instituições financeiras mantidas pela ONU e por outros organismos internacionais (Fundo Monetário Internacional, Banco Internacional para o Desenvolvimento Econômico - BIRD), com bancos estrangeiros ou através de títulos colocados nos mercados internacionais de capitais $^{506}$.

501 ASSONI FILHO, Sérgio. Crédito público e responsabilidade fiscal, p. 56.

502 OLIVEIRA, Regis Fernandes de. Curso de direito financeiro, p. 672.

${ }^{503}$ ATALIBA, Geraldo. Empréstimos públicos e seu regime jurídico, p. 75.

504 TORRES, Ricardo Lobo. Curso de direito financeiro e tributário, p. 220-221.

505 TORRES, Ricardo Lobo. Curso de direito financeiro e tributário, p. 220-221.

506 TORRES, Ricardo Lobo. Curso de direito financeiro e tributário, p. 221. 
O Senado Federal brasileiro, de acordo com o art. 3º da Resolução n. 43/2001, adota esse critério ao definir operação de crédito conforme a seguir:

(...) compromissos assumidos com credores situados no País ou no exterior, em razão de mútuo, abertura de crédito, emissão e aceite de título, aquisição financiada de bens, recebimento antecipado de valores provenientes da venda a termo de bens e serviços, arrendamento mercantil e outras operaçôes assemelhadas, inclusive com o uso de derivativos financeiros.

Já Fernando Sainz de Bujanda ${ }^{507}$ assinala que "la Deuda pública podrá estar denominada en pesetas o en moneda extranjera y emitirse tanto en el interior como en el exterior" e, com isso, adota a nacionalidade da moeda para diferenciar a dívida pública externa da interna.

Como se vê, a norma e a doutrina adotam critérios diversos para distinguir a dívida pública entre interna e externa e, ainda que referidas classificações se mostrem irrelevantes à primeira vista, deve-se considerá-las não apenas como um simples critério de classificação, mas, também, com base nas consequências advindas da contração de uma ou de outra, no que toca aos efeitos que podem ser gerados.

A propósito, mostram-se pertinentes e oportunas as considerações de Alejandro Ramirez Cardona ${ }^{508}$, cujo critério de diferenciação adotado é o do local de negociação, ou, como prefere o autor, o círculo econômico de onde provém o capital.

Para Alejandro Cardona, o Estado, ao contrair a dívida no mercado interno, não produz o desejado aumento da renda nacional, pois o dinheiro circula apenas nas mãos do prestamista e da entidade tomadora, e sua utilização dar-se-á apenas para regular a economia em períodos de inflação. Já a dívida contraída no exterior implicaria evidente mudança de "círculo econômico", ou seja, ingresso de recursos monetários provenientes de uma economia distinta, pois este não pertence ao ente público mutuário e os recursos são, geralmente, empregados na realização de investimentos e em infraestrutura, proporcionando a distribuição de renda.

507 BUJANDA, Fernando Sainz de. Lecciones de derecho financiero, p. 408.

508 CARDONA, Alejandro Ramirez. Sistema de hacienda pública, p. 419-420: "El empréstito interno. El empréstito interno sustrae capital del mismo circuito económico a que pertenece el ente público prestatario. La modalidad interna de empréstito se utiliza para la cobertura de los más variados gastos, desde los de funcionamiento hasta los de inversión y trasferencia. (...). El empréstito interno no aumenta la renta nacional: parte de ella pasa de unas manos a otras, de los particulares al ente público, que la devuelve luego en intereses y amortización. (...). El empréstito externo. El empréstito externo toma dinero prestado de otro circuito económico distinto al que pertenece el ente público prestatario. Esta modalidad de empréstito se destina generalmente a gastos de inversión productiva e infraestructurales." (grifo do original). 
Com isso, verifica-se que a adoção de políticas deve ser devidamente planejada, levando em conta as distinções apontadas, a fim de que se possam evitar ou minimizar resultados indesejáveis. Devem-se, ainda, estabelecer margens para as reações provocadas no mercado interno.

\subsubsection{Dívida flutuante e dívida fundada ou consolidada}

O critério utilizado para distinguir a dívida pública flutuante da fundada ou consolidada, a despeito das severas críticas tecidas por Geraldo Ataliba ${ }^{509}$, ainda continua sendo o do prazo de duração, ou seja, o prazo durante o qual há de ser pago e extinto o contrato de empréstimo público ${ }^{510}$.

$\mathrm{Na}$ lição de Aliomar Baleeiro, "a dívida flutuante se caracteriza pelos vencimentos em termos brevíssimos, como meses ou um ano no máximo" e "é contraída para suprir os embaraços de tesouraria: a) para cobrir o déficit; b) porque as receitas só ingressam no Tesouro em época posterior à necessidade de realização de despesas prementes ou com vencimento em data fixada na lei" ${ }^{11}$.

A aparição constitucional dessa modalidade de dívida se dá, ainda que de maneira sutil, no art. $165, \S 8^{\circ}$, cuja referência é feita nas entrelinhas ao estabelecer as exceções ao princípio orçamentário da exclusividade; consta, expressamente, da Lei Federal n. 4.320/1964, no art. 92, segundo o qual compreende a dívida flutuante: (i) os restos a pagar; (ii) os serviços da dívida a pagar; (iii) os depósitos; e (iv) os débitos de tesouraria ${ }^{512}$.

Além disso, a LRF, no art. 38, conceitua a dívida flutuante quando faz menção às operações de crédito por antecipação de receitas orçamentárias, assinalando que estas se destinam a atender à insuficiência de caixa durante o exercício financeiro, e desde que atendidas, também, as exigências constantes do art. 32.

No que tange ao prazo de resgate, este é deduzido do disposto no art. 28 da Lei Federal n. 4.320/1964 e no $\$ 3^{\circ}$, do art. 29, da LRF, os quais estabelecem, respectivamente, que "a dívida fundada compreende os compromissos de exigibilidade superior a 12 (doze) meses"; e que "também integram a dívida pública consolidada as operaçôes de crédito de prazo inferior a 12 (doze) meses".

Tem-se, assim, que a dívida pública consolidada ou fundada é o "montante total, apurado sem duplicidade, das obrigaçôes financeiras do ente da Federação,

509 ATALIBA, Geraldo. Empréstimos públicos e seu regime jurídico, p. 81-87.
510 BALEEIRO, Aliomar. Uma introdução à ciência das finanças, p. 484.
511 BALEEIRO, Aliomar. Uma introdução à ciência das finanças, p. 484.
512 ASSONI FILHO, Sérgio. Crédito público e responsabilidade fiscal, p. 58-59. 
assumidas em virtude de leis, contratos, convênios ou tratados e de realização de crédito, para amortização em prazo superior a 12 (doze) meses" (art. 29, I, da LRF).

As distinções em referência, legais, coadunam-se com o conceito proposto por Regis Fernandes de Oliveira ${ }^{513}$, o qual une o critério da finalidade ao do prazo de duração, ao esclarecer que dívida flutuante é aquela adquirida para suprir deficiência de caixa e deve ser resgatada no curto prazo, constituindo, assim, uma situação provisória, enquanto a dívida consolidada ou fundada tem prazo longo e se destina à realização de investimentos.

Giovanni Ingrosso ${ }^{514}$ adota essa mesma concepção, para salientar que a dívida flutuante é qualificada quase pela totalidade da doutrina como empréstimos temporários, provisórios ou transitórios, pois estes são contratados por um período não superior a um ano e detêm a função de suprir a momentânea exigência de caixa do tesouro.

Além disso, conforme anota Geraldo Ataliba ${ }^{515}$, "a operação de crédito por antecipação de receita é um tipo de empréstimo que o poder público faz com a exclusiva finalidade de suprir eventuais quedas de arrecadação”, as quais se equiparam à dívida flutuante, pois detém as seguintes características: "o curto prazo; o volume reduzido e sempre proporcional, não só às necessidades de pagamento dentro do curto prazo; e a sua aplicação em despesas corriqueiras da própria administração".

A propósito, Regis Fernandes de Oliveira ${ }^{516}$ informa que o texto constitucional brasileiro traz um único exemplo, no $\$ 8^{\circ}$ do art. 165 . O autor destaca, ainda, que a Constituição Federal de 1988 não reproduziu o disposto na anterior, a qual atribuía limites a esse tipo de operação, estabelecendo limites e prazos.

Regis Fernandes de Oliveira também observa que as operações aludidas estão disciplinadas no art. $14^{517}$ da Resolução n. 43/2001 do Senado Federal, e que elas independem de autorização deste ${ }^{518}$.

513 OLIVEIRA, Regis Fernandes de. Curso de direito financeiro, p. 673.

514 INGROSSO, Giovanni. Corso di finanza pubblica, p. 560.

515 ATALIBA, Geraldo. Empréstimos públicos e seu regime jurídico, p. 105-106.

516 OLIVEIRA, Regis Fernandes de. Empréstimos públicos no Brasil. In: MELLO, Celso Antônio Bandeira de (Org.). Estudos em homenagem a Geraldo Ataliba: direito tributário. São Paulo: Malheiros, 1997. v. I, p. 245.

517 Conforme teor do art. 14, "A operação de crédito por antecipação de receita orçamentária deve cumprir as seguintes condições:

I - realizar-se somente a partir do décimo dia do início do exercício; 
É importante observar, que, conforme dispõe o texto constitucional, a suspensão do pagamento da dívida flutuante por mais de dois anos consecutivos, salvo motivo de força maior, constitui causa de intervenção federal (art. 34, V, a). No mesmo sentido, a inadimplência da dívida fundada por dois anos consecutivos sem motivo de força maior dá ensejo à intervenção estadual (art. 35, I).

No mais, e diante das distinções propostas, é de relevância fazer menção às consideraçôes de Émerson César da Silva Gomes, ao alertar para as mudanças introduzidas pela LRF, as quais teriam implicado a alteração do critério de distinção entre dívida flutuante e dívida fundada, não mais subsistindo o critério do prazo de exigibilidade, mas, sim, o da autorização legislativa. Veja-se:

Assim, com o advento da LRF, melhor dizer que a dívida flutuante é aquela classificada no passivo financeiro (art. 105, $\$ 3^{\circ}$, da Lei n. 4.320/1964), ou seja, é aquela cujo pagamento independe de autorização orçamentária.

A dívida fundada, por sua vez, é aquela classificada no passivo permanente (art. 105 $\$ 4^{\circ}$, da Lei n. 4.320/1964), cujo pagamento depende de autorização legislativa para amortização ou resgate ${ }^{519}$.

No entanto, em face das menções anteriores e levando-se em conta o quanto expresso nos dispositivos constitucionais citados, ainda hoje é possível concluir que a Lei Maior brasileira adotou o critério temporal como sendo determinante para distinguir a dívida flutuante da fundada, ainda que guarde certa consonância com o critério da autorização legislativa.

\subsubsection{Dívida mobiliária}

Prevista na Constituição Federal brasileira (art. 52, IX), a dívida mobiliária é definida pela Secretaria do Tesouro Nacional como sendo a "dívida pública repre-

II - ser liquidada, com juros e outros encargos incidentes, até o dia 10 (dez) de dezembro de cada ano;

III - não será autorizada se forem cobrados outros encargos que não a taxa de juros da operação, obrigatoriamente prefixada ou indexada à taxa básica financeira, ou à que vier a esta substituir;

IV - será vedada enquanto existir operação anterior da mesma natureza não integralmente resgatada.".

518 OLIVEIRA, Regis Fernandes de. Curso de direito financeiro, p. 696.

519 GOMES, Émerson César da Silva. Das autarquias e outras entidades. In: CONTI, José Maurício. Orçamentos públicos: a Lei n. 4.320/1964 comentada, p. 328. 
sentada por títulos públicos emitidos pelo Tesouro Nacional" ${ }^{520}$. Saliente-se que é competência privativa do Senado Federal estabelecer os limites e condições da dívida mobiliária dos entes da Federação, à exceção da União.

Observa-se que a referida Secretaria se vale da definição apresentada no inc. II $^{521}$ do art. 29 da LRF, o que diferencia a dívida mobiliária da dívida consolidada, a qual detém origem nas obrigações financeiras assumidas em face de leis, contratos, convênios ou tratados e da realização de operações de crédito, cuja amortização se dê em prazo superior a doze meses, conforme inc. I do dispositivo em questão.

A dívida mobiliária federal é composta pela soma de tudo aquilo que todos os órgãos do Estado brasileiro devem, incluindo o Governo Federal, os Estados, os Municípios e o próprio Banco Central, devendo seu limite estar previsto em ato do Congresso Nacional (art. 48, XIV, da CF/1988), ao passo que a dívida consolidada da União deve estar prevista em resolução do Senado Federal (art. 52, VI, da $\mathrm{CF} / 1988)$.

Com o art. 29 da LRF, é possível afirmar que se atribuiu um regime específico para a dívida mobiliária, estabelecendo, além de sua composição, a possibilidade de ser o principal refinanciado, desde que não exceda, ao término de cada exercício financeiro, o montante do final do exercício anterior, somadas as operações de crédito autorizadas no orçamento e efetivamente realizadas, acrescido de atualização monetária (art. 29, $\$ 4^{\circ}$, da LRF).

Ressalte-se que, além disso, o refinanciamento da dívida mobiliária não se sujeita a determinadas vedações, tal qual se verifica com as operaçôes de crédito, em que, não observados determinados limites, impedem o ente de realizar operações de crédito internas e externas, inclusive por antecipação de receita (art. 31, $\$ 1^{\mathrm{o}}$, I, da LRF).

Por fim, cumpre anotar que as operaçōes inerentes à dívida mobiliária federal gozam de tratamento especial no que se refere à aprovação e controle pelo Ministério da Fazenda - seu procedimento é simplificado (art. 32, $\$ 2^{\circ}$, da LRF) e a aquisição de títulos da dívida da União é permitida aos Estados e Municípios (art. $35, \$ 2$ o, da LRF), ao contrário das demais operaçôes de crédito, cuja realização entre os entes da Federação é vedada, nos termos do caput do art. 35 da LRF.

${ }^{520}$ Disponível em: <http://www3.tesouro.fazenda.gov.br/servicos/glossario/glossario_d.asp>. Acesso em: 17 out. 2014.

521 O referido inciso tem o seguinte teor: "II - dívida pública mobiliária: dívida pública representada por títulos emitidos pela União, inclusive os do Banco Central do Brasil, Estados e Municípios.”. 


\subsection{HISTÓRICO DA DÍVIDA PÚBLICA BRASILEIRA E OS LIMITES DE ENDIVIDAMENTO}

Diante do quanto até então apresentado sobre dívida pública, pode-se afirmar que suas principais alterações decorrem de mudança de ideologia bastante significativa envolvendo o sistema financeiro, decorrentes do Estado Liberal e da estrutura capitalista.

Essa mudança eleva os impostos ao posto de principal fonte de recursos públicos, e os empréstimos financeiros deixam de ser utilizados pelos Governos como mera receita extraordinária. Os empréstimos assumem, com isso, a função de antecipar a arrecadação tributária e de sustentar os investimentos de longo prazo.

No entanto, no Brasil, como será observado a seguir, a dificuldade em administrar a dívida pública e a ineficiência de se valer desse importante instrumento de antecipação de receita acarretaram vários problemas e prejuízos ainda hoje sentidos.

A exemplo de outros países - como Portugal e Espanha, em que o patrimonialismo impera há décadas -, a história tem demonstrado que a utilização da dívida pública sem planejamento e responsabilidade, somada a outros fatores como a corrupção, eleva o nível de despesas dos Estados com o pagamento de juros mais altos, emperram o desenvolvimento e acarretam danos irreparáveis à sociedade e à economia.

\subsubsection{Breve escorço histórico}

Antes de se separar da metrópole (Portugal), o Brasil "ainda não tinha uma dívida pública no sentido técnico da palavra, embora governadores e veneranças da colônia contraíssem empréstimos desde os séculos XVI e XVII"522.

Como esclarece Anderson Caputo Silva ${ }^{523}$, nessa época, os empréstimos públicos se confundiam com os empréstimos pessoais dos governantes e tudo era desconhecido: o tamanho da dívida, a finalidade do empréstimo, as condições em que era realizado etc.

Foi nesse período, todavia, que se verificou o início da dívida pública brasileira. Enquanto tropas de Napoleão Bonaparte invadiam Portugal, a Coroa portuguesa se transferia para cá e consigo trazia a dívida contraída perante a Inglaterra ${ }^{524}$.

BALEEIRO, Aliomar. Uma introdução à ciência das finanças, p. 437.

${ }^{523}$ SILVA, Anderson Caputo. Origem e história da dívida pública no Brasil até 1963. In: SILVA, Anderson Caputo; CARVALHO, Lena Oliveira de; MEDEIROS, Otavio Ladeira de (Orgs.). A divida pública: a experiência brasileira. Brasília: Secretaria do Tesouro Nacional; Banco Mundial, 2009. p. 33. Disponível em: <http://www3.tesouro.gov.br/divida_publica/downloads/livro/livro_eletronico_completo.pdf>. Acesso em: 26 ago. 2013.

${ }^{524}$ OLIVEIRA, Regis Fernandes de. Curso de direito financeiro, p. 684. 
Os fatos e ações marcantes para a história política, econômica e financeira do Brasil também se deram nessa época, podendo-se destacar (i) a abertura de portos em 1808; (ii) a criação do primeiro Banco do Brasil; e (iii) a implantação do papel- moeda $a^{525}$.

Marcado pelas dificuldades financeiras enfrentadas no período que antecedeu à sua independência, o Brasil, nesses primeiros anos, também tinha de enfrentar as demandas naturais. Esses fatos tornaram a história da dívida brasileira rica em vários aspectos: (i) criou-se a primeira agência de administração da dívida pública; (ii) institucionalizou-se a dívida pública interna; (iii) ampliaram-se os mecanismos e instrumentos de financiamento; e (iv) realizaram-se operaçôes de reestruturação de dívida ${ }^{526}$.

Ainda no Brasil Império, mediante comissão instituída por D. Pedro I, expede-se a Lei de 15 de novembro de 1827, responsável por fundar a dívida pública interna e externa e criar o Grande Livro e a Caixa de Amortização 527 , a qual, "considerada por muitos a pedra fundamental do crédito público no Brasil, sofreu poucas alterações até a criação do Banco Central, quase 140 anos depois" ${ }^{28}$.

Já no período da República, a história da dívida pública é marcada por uma fase de dificuldades de financiamento interno e externo e de reestruturações que culminaram com a suspensão de pagamentos do serviço da dívida (funding loan), em 1989, 1914 e 1931, até que, em 1943, o Brasil firmou o denominado "acordo permanente da dívida externa" 529 .

A dívida externa servia, à época, "para aparelhar o país de seus serviços essenciais, que não existiam ao tempo da Independência, e também para socorro do Tesouro, que sempre vacilara em lançar mão da tributação eficaz" ${ }^{530}$.

525 SILVA, Anderson Caputo. Origem e história da dívida pública no Brasil até 1963. In: SILVA, Anderson Caputo; CARVALHO, Lena Oliveira de; MEDEIROS, Otavio Ladeira de (Orgs.). A divida pública: a experiência brasileira, p. 35.

526 SILVA, Anderson Caputo. Origem e história da dívida pública no Brasil até 1963. In: SILVA, Anderson Caputo; CARVALHO, Lena Oliveira de; MEDEIROS, Otavio Ladeira de (Orgs.). A divida pública: a experiência brasileira, p. 36.

${ }^{527}$ OLIVEIRA, Regis Fernandes de, op. cit., p. 684.

528 SILVA, Anderson Caputo. Origem e história da dívida pública no Brasil até 1963. In: SILVA, Anderson Caputo; CARVALHO, Lena Oliveira de; MEDEIROS, Otavio Ladeira de (Orgs.). A divida pública: a experiência brasileira.

529 SILVA, Anderson Caputo. Origem e história da dívida pública no Brasil até 1963. In: SILVA, Anderson Caputo; CARVALHO, Lena Oliveira de; MEDEIROS, Otavio Ladeira de (Orgs.). A divida pública: a experiência brasileira, p. 44-54.

530 BALEEIRO, Aliomar. Uma introdução à ciência das finanças, p. 440. 
Ainda que esse acordo tenha implicado a redução do nível de endividamento do Brasil, o País voltou, no início dos anos 1950, a sofrer desequilíbrios em suas contas internas e externas. Seu limite de endividamento dobrou entre 1946 e 1953, alcançando mais de US \$ 1 bilhão. Por conta da política de expansão implementada por Juscelino Kubitschek no programa de metas (1957-1960), em 1961 a dívida pública externa total já alcançava o dobro dos níveis de 1955, e a situação do balanço de pagamentos era desastrosa, o que não se alterou nos períodos que se sucederam, nos governos de Jânio Quadros e João Goulart ${ }^{531}$.

Regis Fernandes de Oliveira ${ }^{532}$, em breve síntese, esclarece que o aumento do endividamento se verifica durante os governos Vargas e Kubitschek, com a construção da rodovia Transamazônica, da ponte Rio-Niterói, de usinas nucleares etc.

A partir de 1964, e já no Governo do Marechal Humberto de Alencar Castello Branco, tem-se um novo marco histórico do ponto de vista político e econômico. Com a determinação de gerar um padrão de desenvolvimento sustentável para o País, foram criados o Banco Central e o Conselho Monetário Nacional, por meio da Lei n. 4.595, de 31 de dezembro de 1964, e, em 1965, instituiu-se o Plano de Ação Econômica do Governo (Paeg). Esse Plano foi concebido com o propósito de, dentre outros objetivos, reduzir as taxas de inflação, implicando a necessidade de se promover reformas no sistema financeiro nacional, a fim de contemplar o desenvolvimento de um mercado eficiente de títulos públicos e, com isso, propiciar tanto a demanda para o financiamento dos déficits públicos quanto a viabilização das operações de política monetária e realização de investimentos ${ }^{533}$.

Essas ações possibilitaram que, no final da década de 1960 e início dos anos 1970, fossem obtidos resultados positivos: (i) as taxas de crescimento da economia apresentavam níveis elevados; e (ii) a inflação atingia níveis inferiores aos observados na segunda metade da década anterior. O Brasil passou a emitir regularmente títulos prefixados e inaugurou o processo de lançamento desses títulos por meio de oferta pública (leilão).

Em meados da década de 1970, o País começou a sentir os efeitos do primeiro choque do petróleo e, em 1974, duplicaram-se as taxas de inflação, e o crescimento da economia cessou, o que se agravou com a segunda crise do petróleo em 1979,

531 BALEEIRO, Aliomar. Uma introdução à ciência das finanças, p. 54.

532 OLIVEIRA, Regis Fernandes de, op. cit., p. 685.

533 PEDRAS, Guilherme Binato Villela. História da dívida pública no Brasil: de 1964 até os dias atuais. In: SILVA, Anderson Caputo; CARVALHO, Lena Oliveira de; MEDEIROS, Otavio Ladeira de (Orgs.). A dívida pública: a experiência brasileira, p. 58-59. 
momento em que "a inflação atingiu patamares sem precedentes, alcançando a barreira dos três dígitos, e as taxas de crescimento da economia começaram a enveredar para o terreno negativo" 534 .

No ano de 1982, e já no Governo de João Batista de Oliveira Figueiredo, término do ciclo militar, o Brasil devia US\$ 100 bilhões. Os empréstimos eram obtidos de empresas multinacionais ou dos Estados Unidos, em substituição à Inglater$\mathrm{ra}^{535}$. Em 1986, foram adotadas medidas profundas, visando alcançar maior controle fiscal, o que resultou na criação da Secretaria do Tesouro Nacional, mediante o Decreto n. 92.452, de 10 de agosto de 1986, com o propósito de centralizar o controle dos gastos públicos ${ }^{536}$.

Os insucessos das políticas levadas a cabo pelo Governo no combate da inflação, todavia, impuseram a adoção de medidas mais enérgicas. A primeira deu-se em 1986, com o Plano Cruzado, em que se verificou (i) o congelamento de preços; (ii) o fim da correção monetária e redução das taxas reais de juros; e (iii) a criação da Letra do Banco Central (LBC), cuja principal característica era ter sua remuneração atrelada à taxa do Sistema Especial de Liquidação e de Custódia (Selic), com indexação diária. Além dessas medidas, o Governo instituiu o Decreto-Lei n. 2.376/1987, criando as Letras Financeiras do Tesouro (LFTs), cujas características eram idênticas às da LBC, destinavam-se especificamente ao financiamento dos déficits orçamentários ${ }^{537}$.

O insucesso do Plano Cruzado fez que o início de 1987 ficasse marcado por sérias dificuldades na condução da política econômica, que provocaram a total perda do controle do déficit público, agravada em 1988, em face da promulgação da Constituição Federal, bem como da impossibilidade de o Banco Central emitir títulos e, portanto, de financiar o governo ${ }^{538}$.

${ }^{534}$ PEDRAS, Guilherme Binato Villela. História da dívida pública no Brasil: de 1964 até os dias atuais. In: SILVA, Anderson Caputo; CARVALHO, Lena Oliveira de; MEDEIROS, Otavio Ladeira de (Orgs.). A dívida pública: a experiência brasileira, p. 61.

535 OLIVEIRA, Regis Fernandes de. Curso de direito financeiro, p. 685.

536 PEDRAS, Guilherme Binato Villela. História da dívida pública no Brasil: de 1964 até os dias atuais. In: SILVA, Anderson Caputo; CARVALHO, Lena Oliveira de; MEDEIROS, Otavio Ladeira de (Orgs.). A dívida pública: a experiência brasileira, p. 62.

537 PEDRAS, Guilherme Binato Villela. História da dívida pública no Brasil: de 1964 até os dias atuais. In: SILVA, Anderson Caputo; CARVALHO, Lena Oliveira de; MEDEIROS, Otavio Ladeira de (Orgs.). A divida pública: a experiência brasileira, p. 63.

538 PEDRAS, Guilherme Binato Villela. História da dívida pública no Brasil: de 1964 até os dias atuais. In: SILVA, Anderson Caputo; CARVALHO, Lena Oliveira de; MEDEIROS, Otavio Ladeira de (Orgs.). A divida pública: a experiência brasileira, p. 64. 
Em 1990, o estoque de títulos em mercado representava 15\% do PIB, e a inflação se encontrava em níveis superiores a $1.000 \%$ ao ano ${ }^{539}$. Esse quadro, por si só, demonstra o nível de descontrole da política econômica e financeira.

Dá-se, aí, a segunda medida austera, com a instituição do Plano Collor, cujo objetivo explícito era pôr fim ao processo inflacionário e ao descontrole fiscal vivenciado nos últimos anos. Para tanto, determinou o congelamento de $80 \%$ dos ativos financeiros do País, promoveu a substituição dos indexadores da dívida e, com isso, uma profunda redução na liquidez da economia, até que se verificou uma queda histórica no estoque da dívida em poder do público, de $82,5 \%$, ainda em 1990. Pouco tempo depois, a dívida e a inflação começaram a se elevar, a ponto de alcançar, em meados da década de 1990 , a taxa de $24,8 \%$ ao ano ${ }^{540}$.

Com o fim da era Collor, marcada pelo impeachment do Presidente e início do Governo de Itamar Franco, sobreveio o Plano Real. Instituído em 27 de fevereiro de 1994, pela Medida Provisória n. 434, o Plano contemplou uma série de medidas para debelar a crise: (i) criou a Unidade Real de Valor (URV); (ii) estabeleceu, dentre outras, regras de conversão e uso de valores monetários; (iii) iniciou a desindexação da economia, privatização de estatais, corte de despesas, aumento dos impostos federais em cinco pontos percentuais e, ainda, determinou o lançamento de uma nova moeda, o Real.

O Plano Real, considerado a medida econômica mais ampla já realizada no Brasil, teve como objetivo principal o controle da hiperinflação, que assolava o país. Vários instrumentos econômicos e políticos foram utilizados para promover a redução da inflação, tendo alcançado, em junho de 1994, o patamar de 46,58\% ao mês. Esses mecanismos contribuíram para a queda do nível de endividamento e da inflação, até que, diante da percepção mais otimista dos investidores sobre os rumos da economia, o Brasil retomou seu crescimento e conseguiu estabilizar a moeda.

Somam-se a esse conjunto de medidas, a edição da Lei n. 9.496, de 11 de setembro de 1997, por meio da qual a União estabeleceu critérios para a consolidação, assunção e refinanciamento, dentre outros, da dívida pública mobiliária que era de responsabilidade dos Estados e do Distrito Federal.

539 PEDRAS, Guilherme Binato Villela. História da dívida pública no Brasil: de 1964 até os dias atuais. In: SILVA, Anderson Caputo; CARVALHO, Lena Oliveira de; MEDEIROS, Otavio Ladeira de (Orgs.). A divida pública: a experiência brasileira, p. 64.

${ }^{540}$ PEDRAS, Guilherme Binato Villela. História da dívida pública no Brasil: de 1964 até os dias atuais. In: SILVA, Anderson Caputo; CARVALHO, Lena Oliveira de; MEDEIROS, Otavio Ladeira de (Orgs.). A dívida pública: a experiência brasileira, p. 65. 
Criou-se, também, por intermédio de referida lei, o programa de apoio à reestruturação e ao ajuste fiscal, no qual foram estabelecidas metas e compromissos a serem realizados pelos Estados e pelo Distrito Federal, no tocante (1) à dívida financeira em relação à receita líquida real (RLR); (ii) ao resultado primário, entendido como a diferença entre as receitas e despesas não financeiras; (iii) às despesas com funcionalismo público; (iv) à arrecadação de receitas próprias; (iv) à privatização, permissão ou concessão de serviços públicos, reforma administrativa e patrimonial; e (v) às despesas de investimento em relação à RLR (art. $2^{\circ}$ ).

Em 24 de agosto de 2001, com a edição da Medida Provisória n. 2.185-35, concedeu-se autorização à União Federal para assumir as obrigaçôes dos Municípios com instituições financeiras nacionais e estrangeiras, e refinanciá-las dentro dos prazos e critérios de pagamento nela fixados. A Medida também vedou a contratação de novas operações de crédito superiores à razão entre a dívida financeira e a receita líquida real do Município cuja dívida fosse refinanciada pela União.

Por fim, destaca-se a Lei de Responsabilidade Fiscal - Lei Complementar n. 101, de 4 de maio de 2000 -, a qual estabelece normas de finanças públicas destinadas a atribuir maior responsabilidade na gestão fiscal, pressupondo a ação planejada e transparente e, com isso, prevenir riscos e corrigir desvios capazes de afetar o equilíbrio econômico das contas públicas, mediante o cumprimento de metas de resultados entre receitas e despesas.

Adotadas essas medidas, as quais contribuíram para maior responsabilidade da gestão pública - e que estão sendo honradas -, verificou-se um aumento da credibilidade do Governo brasileiro e da economia, permitindo a estabilização da moeda e a retomada do crescimento.

No entanto, informações prestadas pela Secretaria do Tesouro Nacional e pelo Ministério da Fazenda em janeiro de 2014 dão conta que, atualmente, o montante da dívida pública federal em 2013 - a qual inclui tudo que o Governo deve aos credores dentro e fora do País - fechou em R \$ 2,12 trilhões, o que corresponde ao aumento de $5,71 \%$ em relação ao exercício anterior ${ }^{541}$. Esses dados têm se mostrado preocupantes, haja vista o aumento do nível de endividamento, da inflação e a redução do índice de crescimento da indústria, comércio e economia.

${ }^{541}$ Disponível em: <http://g1.globo.com/economia/noticia/2014/01/divida-publica-sobe-57-em2013-e-atinge-marca-inedita-de-r-212-tri.html>. Acesso em: 18 out. 2014. 


\subsubsection{Requisitos e limites do endividamento público federal}

Como já assinalado, os Estados, assim como as pessoas privadas, recorrem a empréstimos e financiamentos de toda ordem para cumprir seus objetivos e finalidades. Para tanto, tomam recursos de instituiçóes financeiras, empresas e outras pessoas jurídicas de direito pública e, até mesmo, de pessoas físicas, quando lançam títulos ao mercado.

No entanto, no âmbito público a contração de dívidas se dá de maneira um pouco diversa daquela que se verifica no âmbito privado, em que o crédito é concedido de acordo com o grau de confiança (fidúcia) atribuído pela entidade financeira e das garantias ofertadas por aquele que deseja obter o empréstimo.

De início, para contrair a dívida, o Brasil necessita de prévia autorização legislativa; depois, é necessário que haja a representação do ente público, fixando as condições, como, por exemplo, garantias, prazos de vencimento, formas de resgate etc. $^{542}$

A Constituição Federal brasileira atribui as obrigações mencionadas ao Senado Federal, responsável, como já esboçado, por autorizar as operações externas de natureza financeira; fixar, mediante proposta do Presidente da República, os limites globais para o montante da dívida consolidada da União e dos demais entes federativos, bem como por dispor sobre os limites globais e condiçôes para ambas as operaçōes de crédito externo e interno (art. 52, V, VI e VII, da CF/1988).

Como se vê, a autorização para contrair dívida limita-se à operação de crédito externa (art. 52, VII, da CF/1988), a qual, embora se esteja tratando apenas da União Federal, alcança todos os entes federativos. Em suma, "nenhum ente público pode realizar qualquer operação externa sem a autorização do Senado" ${ }^{433}$.

As dívidas públicas consolidadas e mobiliárias dos Estados, Municípios e o Distrito Federal, assim como as respectivas administrações diretas, os fundos, as autarquias, as fundaçōes e as empresas estatais dependentes, sujeitam-se às regras da Resolução do Senado Federal n. 40/2001, já mencionada. Essa Resolução veda qualquer operação que implique endividamento, sem o cumprimento de determinações e sem a prévia previsão orçamentária, bem como estipula que, a partir de 2016, as dívidas consolidadas líquidas não poderão ser superiores a 200\% das receitas correntes líquidas, no caso dos Estados, ou a 120\%, em se tratando dos Municípios.

542 OLIVEIRA, Regis Fernandes de. Curso de direito financeiro, p. 688.

543 OLIVEIRA, Regis Fernandes de. Curso de direito financeiro, p. 688. 
Resolução n. 40/2001 também estabelece que, até o exercício de 2016, eventuais excessos em relação ao limite fixado deverão ser reduzidos na proporção de, no mínimo, $1 / 15$ ao ano.

Entretanto, a Resolução em comento não traz nenhuma previsão no que tange à União, a qual se submete à Resolução do Senado n. 48/2007, cuja disposição trata, dentre outros, dos limites globais para as operaçôes de crédito externo e interno da Uniāo, de suas autarquias e demais entidades controladas pelo poder público federal, bem como estabelece os limites e condições para a concessão de garantia da União em operações de crédito externo e interno, regulamentando, assim, o disposto no inc. V, do art. 52, da CF/1988.

No art. 2o, a Resolução n. 40/2001 redefine alguns conceitos e, no inc. III, define dívida consolidada como sendo o

$$
\begin{aligned}
& \text { (...) montante total, apurado sem duplicidade, das obrigações financeiras da União, } \\
& \text { inclusive as decorrentes da emissão de títulos, assumidas em virtude de leis, contratos, } \\
& \text { convênios ou tratados, da realização de operações de crédito para amortização em } \\
& \text { prazo superior a } 12 \text { (doze) meses, dos precatórios judiciais emitidos a partir de } 5 \text { de } \\
& \text { maio de } 2000 \text { e não pagos durante a execução do orçamento em que hajam sido in- } \\
& \text { cluídos e das operaçôes de crédito que, embora de prazo inferior a } 12 \text { (doze) meses, } \\
& \text { tenham constado como receitas no orçamento. }
\end{aligned}
$$

Ainda, essa Resolução esclarece, no $₫ 2^{\circ}$, que a dívida consolidada não inclui as obrigações existentes entre a Administração direta e as respectivas entidades que integram a União.

Já no art. 7 , dispõe sobre os limites e condições para a realização de operaçôes de crédito, restringindo-as ao montante global de $60 \%$ da receita corrente líquida (inc. I). A respeito do montante da dívida consolidada, determina que esta não poderá exceder o teto estabelecido pelo Senado em resolução específica (inc. II).

De acordo com o art. $8^{\circ}$, os contratos relativos a operaçóes de crédito externo não podem conter nenhuma cláusula de natureza política, atentatória à soberania nacional e à ordem pública ou contrária à Constituição e às leis brasileiras, bem como que implique compensação automática de débitos e créditos.

Preceitua, também, que a União não pode prestar garantia acima de $60 \%$ da receita corrente líquida (art. 9º), as quais somente poderão ser outorgadas, se atendidos os requisitos constantes do art. 10.

Em síntese, essas são as principais merecedoras de destaque, valendo lembrar que, além das considerações e especificidades apontadas, a Constituição Federal (art. 167, III), veda que se realizem operações de créditos que excedam o montante das despesas de capital, com ressalvas para aquelas autorizadas mediante créditos 


\section{•• O orçamento como instrumento de intervenção no domínio econômico}

suplementares ou especiais com finalidade precisa, desde que tenham sido aprovadas pelo Poder Legislativo, por maioria absoluta.

\subsection{A DíVIDA PÚBLICA E O DOMÍNIO ECONÔMICO}

Reitere-se que, como já demonstrado, em geral o Estado, recorre à contratação de empréstimos como meio de obter recursos e os destina não apenas ao pagamento de suas despesas correntes, mas, também, ao atendimento das necessidades públicas.

Sobre essa questão, Aliomar Baleeiro assinala que "o crédito público inclui-se entre os vários processos de que o Estado pode lançar mão para obtenção de fundos, como método fiscal, ou para outros fins extrafiscais" ${ }^{244}$.

Não por menos, afirmou-se que os empréstimos públicos perderam sua característica de extraordinariedade e que sua contração tem se dado não apenas como forma de cobrir deficiências de caixa, mas também, muitas vezes, como instrumento destinado a evitar o aumento da carga tributária ${ }^{54}$.

Daí já se verifica a função extrafiscal da dívida pública a que se refere Giovanni Ingrosso, para o qual a dívida pública assume importante papel de incremento e redistribuição de riquezas. Veja-se:

In quest'ultimo, infatti, si ritrovano enunciate, e regolate in buona parte nella loro concreta realizzazione, le finalità extrafiscali del debito pubblico.

Tali finalitá come si è accennato nel precedente paragrafo, si identificano, in sostanza con quelle proprie dell'attività finanziaria contemporanea, compendiandosi esse nella redistribuzione e nell'incremento del reddito nazionale.

E il debito pubblico è un fattore redistributivo di ricchezza, per constituire un mezzo di distrazione di risparmio individuale privato a favore dell'impiego pubblico ${ }^{546}$.

Além disso, mostrou-se que a necessidade de atender às despesas extraordinárias não constitui o único motivo que pode induzir os responsáveis pela política econômica a optarem pelo crédito público. A contratação do empréstimo pode, também, destinar-se a outros fins e acarretar reflexos diretos sobre a poupança, a produção, oferta e demanda de crédito e, por conseguinte, sobre os interesses políticos, a economia e, não por menos, sobre o domínio econômico.

Saliente-se, ainda, que essa contratação pode, além disso, impactar geraçōes futuras, o que tem gerado, ainda hoje, muita discussão acerca da contratação de empréstimos pelo Estado; afinal, embora a dívida auxilie a obter mais cedo aquilo

${ }^{544}$ BALEEIRO, Aliomar. Uma introdução à ciência das finanças, p. 431.

545 BUJANDA, Fernando Sainz de. Lecciones de derecho financeiro, p. 404.

${ }^{546}$ INGROSSO, Giovanni. Corso di finanza pubblica, p. 547. 
que se deseja, há os defensores da ideia de que os empréstimos repartem com as gerações futuras despesas públicas de hoje. Em outros termos, muitos questionam a legitimidade de se impor às gerações futuras o ônus de pagar as despesas públicas realizadas hoje e em favor das gerações que lhes antecedem.

Embora não constitua objeto de estudo da presente dissertação, defende-se que aqueles contrários à contratação de empréstimos desconsideram a necessidade de aumentar a flexibilidade orçamentária, a melhoria na gestão financeira, a possibilidade de antecipar receitas e, principalmente, a necessidade de dar continuidade à realização das despesas, mormente diante de eventual dificuldade ou queda na arrecadação de impostos.

Seus opositores também desconsideram a possibilidade de distribuir equitativamente, ao longo do tempo e por várias gerações, os custos decorrentes de investimentos que se perpetuarão no tempo, como é caso, por exemplo, de investimentos em infraestrutura e a realização de despesas de capital.

Essas despesas, ao corresponderem à aquisição de um ativo ao patrimônio público, podem gerar recursos, utilidades e benefícios para gerações atuais e futuras, ao contrário do alegado. $\mathrm{Na}$ visão de Aliomar Baleeiro ${ }^{547}$ :

A geração futura ficaria onerada com a amortização, ou com os juros da dívida, mas receberia, como compensação desse ônus, o valor da rede de transportes, das empresas públicas produtivas de receitas originárias, das fortalezas, frotas mercantes de guerra, bens corpóreos etc. O sacrifício da posteridade seria praticamente nulo pelo ativo que se conservaria até a época em que viesse a suportar os ônus financeiros correspondentes.

Ricardo Lobo Torres, no entanto, adverte que "a equidade entre gerações significa que os empréstimos públicos e as despesas governamentais não devam sobrecarregar as gerações futuras, cabendo à própria geração que delas se beneficia arcar com o ônus respectivo" 548 .

Decorre das circunstâncias apontadas a razão pela qual o legislador brasileiro impôs limites à contratação de empréstimos (art. 167, II, da CF/1988), bem como vinculou as operações de crédito à sua exclusiva utilização de acordo com finalidade legal que as motivaram, ao introduzir o parágrafo único ao art. $8^{\circ}$ da LRF (Lei Complementar n. 101, de 4 de maio de 2000).

Tecidas essas considerações, há que se ressaltar que a contratação de empréstimos também tem por finalidade intervir na vida econômica e social, uma vez que,

547 BALEEIRO, Aliomar. Uma introdução à ciência das finanças, p. 449.

548 TORRES, Ricardo Lobo. Tratado de direito constitucional financeiro e tributário, p. 308-309. 


\section{•• O orçamento como instrumento de intervenção no domínio econômico}

a captação de recursos pode estar atrelada à necessidade de fomentar determinada(s) atividade(s) ou setor(es), e até mesmo estimular o crescimento econômico em períodos de recessão.

De acordo com cada motivação, a qual também envolvem circunstâncias pessoais e as paixões daqueles que governam o País, a dívida pública assume um papel diferente. Importante instrumento de que dispõe o Estado para intervir no domínio econômico e social, concretizar sua política financeira e promover o crescimento econômico, é por meio da dívida pública que o Estado, em períodos de recessão, crise ou decréscimo de arrecadação, mantém a política de obras públicas que, sem essa contração de dívida, seriam paralisadas ou até mesmo deixariam de ser executadas ${ }^{549}$.

Nesse aspecto, ganham destaque as ideias keynesianas por colocar em relevo a importância da despesa pública como providência restauradora do consumo, influenciar a decisão de investir e por tornar desaconselhável a tributação violenta, atribuindo aos empréstimos a função de captar recursos para sustentar a política de gastos intensos com o fim de recuperar a prosperidade, o que pode não se alcançar com a majoração ou criação de novos tributos ${ }^{550}$.

Além dos fatores apontados, John Maynard Keynes também atribui ao clima político e social a prosperidade econômica, assinalando que "o fato de o temor a um governo trabalhista ou de um New Deal deprimir o empreendimento não é necessariamente consequência de um cálculo racional ou de manobras com fins políticos" ${ }^{251}$.

Com isso, tem-se que a adoção de determinadas medidas ou escolhas também pode influenciar a economia e o domínio econômico em específico. Ao optar por tomar um empréstimo ao invés de aumentar a carga tributária, certamente reações diversas na economia serão provocadas.

Fernando Sainz de Bujanda ${ }^{552}$ faz uma observação precisa, ao ponderar:

Y no sólo motivos puramente económicos pueden influir en la decisión de emitir títulos de la Deuda. Las ideas del legislador sobre el reparto de las cargas públicas, tanto en el espacio como en el tiempo, las consecuencias sociales (creación de una classe de rentistas, fomento de ahorro, ect.) y las motivaciones de índole política (ventajas e inconvenientes del endeudamiento frente a otro Estado, etc.) pueden determinar la elección de uno u otro método (Deuda, impuesto, etc.) de subvenir a las cargas del Estado.

549 BALEEIRO, Aliomar. Uma introdução à ciência das finanças, p. 453.

${ }^{550}$ BALEEIRO, Aliomar. Uma introdução à ciência das finanças, p. 453.

551 KEYNES, John Maynard. Teoria geral do emprego, do juro e da moeda, p. 145.

552 BUJANDA, Fernando Sainz de. Lecciones de derecho financiero, p. 404. 
Richard A. Musgrave, nesse aspecto, também traz algumas distinçōes.

(...) a escolha entre financiamento por tomada de empréstimo e o que é feito por tributação envolve uma escolha entre retirada de recursos em grande parte da formação de capital privado e uma outra grande parte do consumo privado. Uma política fiscal que tem por alvo acentuar o crescimento confia no financiamento por coleta de impostos, ao passo que a destinada a suportar o consumo presente se apoia no financiamento por empréstimo ${ }^{53}$.

Sem dúvidas, as decisões adotadas pela Administração Pública mexem com a expectativa da iniciativa privada, esquecendo-se, muitas vezes, que "a solvência governamental depende dos poderes produtivos da economia e da capacidade tributável que abrangem" ${ }^{554}$.

Concebe-se, com isso, que o crédito público é um forte instrumento à disposição do Estado para o controle do mercado monetário e de desenvolvimento econômico, social e financeiro, desde que ele, Estado, o utilize de modo responsável e consciente, e em atendimento às próprias finalidades.

553 MUSGRAVE, Richard A. Teoria das finanças públicas, p. 690.

${ }^{554}$ MUSGRAVE, Richard A. Teoria das finanças públicas, p. 696. 
